\title{
6 ECOWAS and the limits of peacemaking in West Africa
}

\author{
Amadu Sesay
}

\section{Introduction}

The Economic Community of West African States (ECOWAS) is arguably the single most important achievement of West Africa's post-independence leaders. The project was aimed at bridging the tangible and intangible legacies of the colonial powers, often referred to as the "Anglophone and Francophone divide in West Africa." A retrospective glimpse at the region before the creation of ECOWAS reveals a geographical space that was replete with "sit-tight leaders," "presidents for life," one-party dictatorships, and tyrannical, retrogressive, plundering civilian and military regimes; it was a severely asphyxiated political space that had little or no respect for basic human rights, human dignity, or security of life. There was absence of region-wide opprobrium and sanctions for those who obtained power through the barrel of a gun or by other unconstitutional means.

The establishment of ECOWAS in 1975 changed the governance, peace, and security landscape in West Africa significantly. ECOWAS was able to noticeably mitigate the debilitating effects of the East-West Cold War rivalry in the region through the deliberate use of "good offices" and "presidential mediation," which resulted in significant fence-mending between and among some of its members, including those that were not on talking terms with one another. ${ }^{1}$ To its credit, ECOWAS has, in the past four decades and a half, facilitated political reconciliation and prevented an outbreak out of hostilities between its members. ${ }^{2}$ The huge success of the European Union (EU), often seen as ECOWAS's "mentor," undoubtedly played an important role in encouraging the leaders in the region to move ahead with the integration project despite the enormous challenges. There was also encouragement from the relative economic success of the BRICS Brazil, Russia, India, China, and South Africa - in that regard (Cheru and Obi, 2010; Southall and Melber, 2009; Vines, Wong, Weimer, and Campos, 2009).

\section{An accidental peace enforcer?}

In assessing the now widely acknowledged success of ECOWAS in restoring relative /peace and stability in West Africa, it is often forgotten that the organisation started its peacemaking role in the region by routinely brokering peace 
between its feuding leaders. It was, however, the cataclysmic post-Cold War conflicts in some member states - most especially Liberia and Sierra Leone that led to their interconnected "uncivil" wars and the deepening of ECOWAS's involvement in peace support operations in the region. The new preoccupation was codified in the 1999 Protocol on the Mechanism for Conflict Prevention, Management, Resolution, Peacekeeping, and Security ("the Mechanism"), which aimed to change responses to domestic peace and security challenges. Another significant development was the involvement in, and support of, key external state and non-state actors to ECOWAS's peacemaking efforts in West Africa in diverse ways: funding meetings and conferences; providing technical expertise through the secondment of senior military personnel at the ECOWAS Commission's headquarters in Abuja; and providing logistics support using development partners, especially during military deployments. Such partnerships with donor countries have been an indispensable catalyst in the implementation of ECOWAS's "expanded mandate" and institution-building, which have also underlined the interconnectedness of economic and politico-security issues in the region.

ECOWAS capitalised on the commitment of regional leaders to stealthily challenge and tone down the emphasis hitherto placed on national sovereignty. Slowly and incrementally, ECOWAS has made important inroads into the traditional preserves of member states and the almost exclusive right to make laws for peace and security, all of which underscored its evolution into a regional security community. This concentration on security is arguably at the expense of growing the economies of member states, wealth creation, and even economic integration, with negative consequences for the organisation's ability to undertake, and sustainably, what I call "hard or lethal peacemaking" activities. ECOWAS presents a salient theoretical and practical innovation and change in integration schemes, most especially in Africa, an unorthodox route to integration in which peace, security, and stability are the most notable catalysts for political and economic integration.

Of particular interest were the extremely inhumane civil wars in Liberia and Sierra Leone in the early 1990s, which inspired unparalleled improvisation by ECOWAS, most notably the deployment of the ECOWAS Cease-fire Monitoring Group (ECOMOG), a precipitate military operation that was believed to have been authorised by the still little-known Community Standing Mediation Committee. ECOMOG troop deployments in Liberia, Sierra Leone, and Guinea-Bissau, and then in Côte d'Ivoire, Mali, and the Gambia, symbolised at a level of analysis a bold attempt to operationalise contemporary pan-Africanism or what has been described as "try Africa first" (Sesay and Omotosho, 2011), which emphasises collective problem-solving at continental and regional levels as an approach to multilateral cooperation and integration. At another level, the deployment of ECOMOG, now institutionalised as the ECOWAS Standby Force (ESF), was a practical expression of the popular phrase "African solutions to African problems" (AfSOL) (Sesay and Omotosho, 2011; Sesay, 2016) in peace and security matters, which is being vigorously promoted by the African Union (AU). 
The ECOWAS Peace and Security Architecture is in tandem with the AU's mechanism, an institutional reflection of the continental body's own expanded mandate. The ESF's capacity is being strengthened for effective deployment within and outside the region at the request of the AU, the United Nations (UN), or any other international organisation. ${ }^{3}$ This is why the ESF has been acknowledged as a model for other Regional Economic Communities (RECs) on the continent. It is arguable that ECOWAS has mastered, consciously and instinctively, what international relations scholars describe as "disjointed incrementalism" in its approach to peacemaking in West Africa, by turning the huge challenges and threats in the region that resulted from the collapse of some member states and the hostile immediate post-Cold War global environment into enormous opportunities for putting in place institutions, mechanisms, and processes for peacemaking and peace enforcement operations that were never anticipated, even in the revised 1993 Treaty. In the process, it engendered irreversible behavioural change among West Africa's leaders and citizens, through institution-building. Some of the more notable landmarks are worthy of a brief mention.

First is the 1978 Protocol on Non-aggression, which aimed to build confidence and discourage interstate conflict in the region. In 1981, the Protocol on Mutual Assistance in Defence (PMAD) was unanimously adopted to compel the organisation to defend any member state that was the victim of external military aggression. President Samuel Doe of Liberia invoked Article 16 of the Protocol in July 1990 in the wake of relentless attempts by Charles Taylor to take over the country by force of arms. A lot has been written on the legality of Doe's letter. Much of the controversy centred on whether, at the time he sent the letter to the ECOWAS Executive Secretary, he was still the country's de jure leader (Aboagye, 1999). Unfortunately, ECOWAS never commented on Doe's letter, which would have given us a fuller background to the decision-making processes that culminated in the deployment of the ECOMOG force in Liberia. The Standing Mediation Committee, however, justified ECOMOG's deployment on the ground as a needed response to the challenging and complex humanitarian emergency in the country, especially in Monrovia. ${ }^{4}$

Other relevant landmarks in mapping ECOWAS's foray into regional peacemaking and peace enforcement include the Mechanism, which placed overwhelming emphasis on multi-track approaches in tackling conflicts in the West Africa region. The Mechanism provided the template for creating other key conflict prevention and peacemaking instruments, such as the Early Warning System, the Council of Elders, the wide-ranging ECOWAS Conflict Prevention Framework, Election Observation, the ECOWAS Court and Parliament, and the ESF. In January 2016, ECOWAS set up the Mediation Facilitation Directorate (MFD) as part of its efforts to consolidate and institutionalise its peacemaking efforts in the region. The broad mandate of the MFD is to "support the Political Affairs Directorate in the coordination and monitoring of mediation efforts by ECOWAS institutions and organs, Member States and non-state actors" (ECOWAS Commission, n.d., 7), and to organise bi-annual exchange programmes to enhance learning, sharing of experiences, and research in dialogue and mediation (ECOWAS Commission, n.d., 8, 11). 
The ECOMOG military operations in Liberia, Sierra Leone, Guinea Bissau, Côte d'Ivoire, Mali, and the Gambia are eloquent testimonies to the strong political will and commitment of West African leaders to engage conflicts in the region head-on. It is irrelevant if deployments and interventions were carried with or without external support. ${ }^{5}$ What is more important is that ECOWAS's huge investment in peacemaking mechanisms and initiatives in West Africa reflects a consciousness by the region's leaders of the unquantifiable costs of violent conflicts on the one hand, and, on the other, the reality that "conflict prevention and peacemaking efforts are not only necessary but imperative if the integration project is to succeed". ${ }^{6}$

The Liberian intervention is particularly significant in tracking the evolution and consolidation of the ECOWAS Peace and Security Architecture. It was the first attempt by a sub-regional organisation in Africa to deploy a peace enforcement force without the explicit approval of the UN Security Council. Second, the subsequent deployment of the UN Observer Mission in Liberia (UNOMIL) several years later presaged the formal involvement of the world body in such a joint venture as a "junior" partner. Third, the intense political and diplomatic shuttles, tensions, negotiations, disagreements, and compromises that characterised the formation and deployment of ECOMOG significantly enhanced political communication between member states as well as their commitment to the expanded ECOWAS project.

These developments become much more meaningful and potent in the context of the perceived Anglophone-Francophone divide; and associated fears of Nigeria's hegemonic intentions in West Africa - what Adebajo has called "pax Nigeriana" (2002; 2004b). ${ }^{7}$ ECOWAS's commitment to promoting peace and security in West Africa underscored the paradoxes between the region's appalling levels of poverty and underdevelopment, and its strong commitment to put together and deploy complex peacekeeping and peace enforcement missions.

It is not surprising, therefore, that the political capital generated by the success of ECOMOG in Liberia and Sierra Leone translated into unprecedented changes in the mandate, objectives, institutional structure, and ideological foundations of not only ECOWAS in West Africa but also of other regional bodies in Africa, especially the Southern African Development Community (SADC). This significant emotional, ideological, and political shift - and even activism - led to the transformation of the essentially redundant OAU into the more pro-active African Union (AU) in July 2002.

Not surprisingly, SADC and similar RECs have made conflict management, including peacekeeping and peace enforcement, a cardinal concern. The mandates of regional and continental bodies in Africa are now more intrusive, while member states are unwittingly surrendering increasing aspects of their sovereignty to continental and regional bodies to enhance the achievement of common goals, especially in the area of peace and security. The restoration of peace and stability in Liberia, Sierra Leone, Guinea-Bissau, Côte d'Ivoire, Mali, and the Gambia has enabled those countries to face the more daunting challenges of nation-building 
and post-conflict reconstruction with some measure of success. Liberia and Sierra Leone have consolidated post-civil war governance gains, and successfully organised a series of presidential and general elections certified as peaceful, free, and fair by ECOWAS, the AU, the EU, the UN, and other international bodies. Notwithstanding the daunting operational limitations and inevitable intraorganisational geopolitical competition, ECOWAS has since the 1990s emerged as the leading and most-experienced actor in peacemaking in Africa. ECOWAS has become an invaluable and indispensable partner of the AU and the UN in promoting peace and security in West Africa. Under the subsidiarity principle, it is ECOWAS, not the AU or the UN, that has primary responsibility for peace and security in the West Africa region.

\section{Irony of success and limits of peacemaking}

A lot has been written on ECOWAS's peacemaking activities (see Adeshina, 2002; Adisa, 1993; Aning, 1994, 1999; Asante, 2004; and Bach, 2004). However, there is a scarcity of literature on the link between ECOWAS's relative success in conflict prevention, management, peacemaking, and security on the one hand, and, on the other hand, its poor record in creating wealth and prosperity among its members through effective economic integration. According to Article 2(1) of the Treaty of Lagos, ECOWAS was set up "to promote cooperation and development in all fields [...] for the purpose of raising the standard of living of its people, fostering closer relations among its members and contributing to the progress and development of the African continent." Through cooperation on socio-economic policies and processes, ECOWAS was to facilitate timely standardisation of tariffs and trade procedures among member states to eventually create a common market, common commercial policy, and external tariffs (Article 58 of the 1975 Treaty).

Another central objective of the organisation was to facilitate the progressive liberalisation of trade within the community, through the elimination of customs duties and administrative and infrastructural barriers to trade among members. The abolition of restrictions on the free movement of people, services, and capital within the sub-region became a critical component of ECOWAS's mandate, which is encapsulated in the 1979 Protocol on Free Movement of Persons and Services. ECOWAS was also to harmonise member states' agricultural and industrial policies; promote joint projects in marketing, research, and agro-industrial enterprises; harmonise planning and implementation of schemes in transportation, communication, and energy sectors; and promote even development among member states through the establishment of a Fund for Cooperation, Compensation, and Development (Article 2[2] 1975 Treaty).

To underline this rather ambitious programme, the founding treaty of ECOWAS implicitly provided for the establishment of a customs union within ten years. As a regional integration scheme, it aimed to enhance the region's development potential by expanding intra-community trade and improving essential physical infrastructure; strengthening members' weak production capacities; 
and promoting monetary and financial cooperation to achieve a single currency. However, Article 58 of the revised 1993 Treaty did not hide the new emphasis on security matters and ECOWAS's unwitting transmutation into a complex security community.

Neglect of the economic integration components of ECOWAS, evidenced by its failure to meet vital community targets and, in particular, its inability to execute community-wide industrial projects, left West Africa far behind other regions in the UN's Human Development Index, with negative consequences for its peacemaking agenda. The failure of the 1987 Economic Recovery Plan, which was already apparent in 1990, pointed to the stagnation as well as the decreasing political commitment of the organisation to its economic targets.

This failure became more pronounced after the 1990s, a period that also coincided with the expansion of its agenda in the non-economic sphere. During this period, most of the development indicators were negative for West Africa (Adedeji, 2004). The unimpressive performance of ECOWAS as an economic integration scheme drew attention from critical stakeholders and official platforms, notably the 21st ECOWAS Council of Ministers. In 2000, ECOWAS's Executive Secretary lamented that, after 25 years, "ECOWAS has shown a poor record with regard to the community programmes" (ECOWAS, 2000).

This is reflected in its inability to fulfil its six cardinal goals, most notably trade liberalisation, well after the 1990 target date; its inability to evolve a common external tariff scheme as a prerequisite for a customs union; limited progress in harmonising economic and fiscal policies among member states; and the continued absence of a single monetary zone across the region. More than four decades after its creation, intra-regional trade was still less than 15 percent of the regional total (Sesay and Akinrinade, 1996; Shuaibu, 2015). ${ }^{8}$ In April 2017, no significant progress had been made either in promoting integration in trade and production or in creating practicable region-wide structures for economic transformation and wealth creation. The modest gains made in the organisation's visa-free policy for community citizens have been bogged down by veiled politico-security restrictions, which are further compounded by terrorism and insurgency in some key member states including Nigeria, Niger, Mali, Burkina Faso, and Côte d'Ivoire. Continued terrorist threats from Boko Haram in Nigeria have increasingly directed the attention of ECOWAS's most powerful member inwards (Runsewe, 2016).

It is apposite therefore to start with a brief look at Nigeria, the most populous member and its biggest economy, which now accounts for 75 percent of West Africa's total GDP and is the biggest economy in Africa ahead of South Africa (UNECA, 2015). Retrospectively, and to its credit, Nigeria led and provided more than 75 per cent of the human and financial resources needed for the Liberia and Sierra Leone operations in the 1990s. Nigeria is presently among those member countries that have been hardest hit by the global economic downturn caused by the COVID-19 pandemic. Crude oil production was already at its lowest level in 30 years between 2016 and the first quarter of 2017 due to the activities of militant groups in the oil-rich Niger Delta. ${ }^{9}$ 
Nigeria's shaky economy had far-reaching implications for the country as well as the entire ECOWAS region, ${ }^{10}$ notably the resultant financial challenges for the regional body. The instability in the price of oil and the effect of insecurity in the Niger Delta on oil production were risk factors for national wealth. ${ }^{11}$ The significance of this for Nigeria and ECOWAS lies in the fact oil sales receipts constitute the biggest chunk of the country's revenue and account for more than 80 percent of total earnings. The Central Bank of Nigeria (CBN) confirmed in July 2016 that crude oil earnings had dropped by as much as NGN 41 billion in one month, and by as much as 18.01 percent in April 2016. ${ }^{12}$ Not surprisingly, the International Monetary Fund (IMF) warned that Nigeria's economy would contract by 1.8 percent in 2016 due to unprecedentedly low oil prices (Vanguard, 2016a).

The significance of this brief politico-economic profile of Nigeria is that, as the region's biggest economy and the most important contributor to ECOWAS's annual budget, the gloomy statistics are directly and indirectly tied to the organisation's financial fortunes and its capacity to undertake autonomous force deployments in the region.

The success of the ECOMOG operations in Liberia and Sierra Leone was mainly due to the total commitment of Nigeria to the project and its relatively buoyant economy at the time. The present poor health of the Nigerian economy, coupled with constitutional checks and balances, makes it difficult for the president to engage in "foreign ventures" like those in Liberia. Another new dimension is the increasingly isolationist tendencies of the Nigerian elite, who openly complain that previous costly foreign adventures in Liberia and Sierra Leone did not yield commensurate dividends in terms of improved welfare for the citizens, or even political support for Nigeria's foreign policy goals in the region, the AU, and the wider international community (Sesay, 2016). ${ }^{13}$ The ongoing insurgency in the northeast of the country, coupled with the disruptive militancy in the Niger Delta, presented security and socio-economic challenges that will make it hard for Nigeria to engage decisively in any future ECOWAS-led military missions in West Africa. ${ }^{14}$ The former President of the ECOWAS Commission, Marcel de Souza, admitted that the organisation was facing challenges including a "financial situation that has become quite precarious and the precarious situation is tied to the economic situation in the Member States and the fact that the price of oil has dropped" (Financial Watch, n.d.; Blank News Online, n.d.). Mr de Souza regretted that the Community Levy, which accounts for 90 percent of ECOWAS's funding, is no longer regularly paid by most member states. The Commission was particularly concerned with the economic fortunes of Nigeria, its "richest" member, stressing that the poor financial state of ECOWAS was undermining its credibility in the region. He appealed to Nigeria to pay up its outstanding bills (Financial Watch, n.d.; Blank News Online, n.d.). The ECOWAS Commission's new political head revealed, openly for the first time, that "the bills of peacebuilding troops sent to Mali and Guinea Bissau were yet to be paid [...] peace comes with a cost that must be paid" (Financial Watch, n.d.; Blank News Online, n.d.). ${ }^{15}$ The Commission's success and failure are intricately tied to the political and economic fortunes of Nigeria, more than any other member state. 
Unfortunately for ECOWAS and its peacemaking efforts in West Africa, the prospects for the rest of the members are no better. According to the UN Economic Commission for Africa (UNECA, 2015, xiii), "in terms of human development, with an average development index of 0.450 for West Africa, most of the countries in the region fall within the category of countries 'with low human development,' besides Cape Verde and Ghana" (UNECA, xiii). Consequently, the chances of attracting significant investment into the region are slim because of its low ranking in the Doing Business Report for 2018. Except for Ghana, which ranked 120th out of 190 countries listed, most West African countries were in the bottom half of the rankings. The low rating of countries in the region in Transparency International's Corruption Perception Index for 2018 shows most countries in West Africa as grappling with major corruption-related challenges. The Ibrahim Index of African Governance also drew attention to the key indicators of poor governance in most of these countries.

Unconstitutional changes of government and coups d'état have significantly receded in the region. Nonetheless, religious extremism and terrorism in some key countries as pointed out earlier remain potent threats to state stability and prosperity in West Africa. Another very compelling threat ECOWAS has yet to find an answer to is the youth bulge, and massive youth unemployment and underemployment in all member states. More than four decades of regional integration have failed to promote inclusive development in the member states, a situation that does not augur well for sustainable peace and stability, given the direct link between youth unemployment, violence, political instability, insurgency, and civil wars. ${ }^{16}$

The Boko Haram insurgency in northeast Nigeria is partially blamed on youth exclusion, massive youth unemployment, and illiteracy. Intricately linked to that is the conclusion by the Ibrahim Index of African Governance that West Africa's democratic institutions and governance systems are weak and could unravel under the weight of youth mass unemployment. The quality of institutions and mechanisms of the organisation are themselves a function of the quality of democratic governance in the member states. Although ECOWAS scores high on the proven political commitment of its members to peacemaking in the region, and has the "blood" - the military and allied personnel for peace enforcement operations - it is severely constrained by its weak "treasury" or fragile financial base. As the Mali After-Action Review (ECOWAS, 2014) eloquently testifies, "ECOWAS lacks the requisite strategic, military, logistical and financial base for autonomous action during violent conflicts in a non-permissive environment" (ECOWAS, 2014, 25). The Africa-led International Support Mission in Mali (AFISMA), which was co-sponsored by the AU and ECOWAS, was eventually taken over by the UN, although the mission was undertaken in "ECOWAS's backyard."

The Mali After-Action Review starkly revealed that the combined efforts of ECOWAS and the AU could not sustain the local funding and ownership of AFISMA, necessitating its re-hatting to create the United Nations Multidimensional Stabilization Mission in Mali (MINUSMA). ECOWAS's poor finances and lack of capacity had resulted in a crisis of self-confidence in its ability to initiate, own, 
and successfully see through military deployments in the region. The Mali AfterAction Review candidly admitted: "the conviction among the ECOWAS Member States that the Region could not intervene militarily in Mali on its own without substantial international logistical and financial support compromised any autonomous military planning from the start" (ECOWAS, 2014, 23). In spite of spirited efforts to institutionalise the ESF, there is no guarantee that the mechanism will be deployed efficiently in a member state. Few members can support their contingents in future military deployments for the statutory 90-day period and ECOWAS may not be able to take over funding such missions in line with global practices. As the Mali After-Action Review poignantly highlighted, "voluntarism and goodwill are not sufficient conditions for the success of a modern Peace Support Operation. Pledges must be backed by redemption" (ECOWAS, 2014, 31). Another serious hurdle to effective future military deployments is the absence of "an effective multidisciplinary Peace Support Operations Division to plan and coordinate operations" at the ECOWAS Commission. In Mali, the functions of this strategic organ were performed by a "cross-departmental Mali Working Group, which was a poor substitute" (ECOWAS, 2014, 31). More than four decades after its formation, ECOWAS has failed to develop the region's "real sectors" upon which national and regional economic development and prosperity hinge (Bach, 1993, 606).

ECOWAS's relative success in peacemaking ventures and initiatives in West Africa has inadvertently led it to adopt a static classical, rather than a robust, dynamic, and pragmatic approach to economic integration. Consequently, it has not been able to build and sustain its capacity to engage decisively in "lethal" peace support operations in West Africa. This shortcoming is compounded by its tendency to mirror similar experiments in Western Europe, notwithstanding the vast differences in their historical, socio-economic, geographical, and political dynamics; a situation that Sesay (2008b) described as "symbolism and impersonation." The structural changes in ECOWAS, including the switch from an ECOWAS Community to an ECOWAS Commission complete with an executive President and Commissioners, underlined the symbolism and impersonation phenomenon on the part of West Africa's flagship regional organisation.

\section{Conclusion}

The central argument in this chapter is that peacemaking and peace support operations are expensive, and presently beyond the means of ECOWAS, because of the appalling economic and security conditions in its members. Of concern is the weak economy in Nigeria, the region's powerhouse and regional hub. Abuja, which had almost singlehandedly led and financed the ECOMOG operations in Liberia and Sierra Leone, is no longer in a position to do so. There is a need for both member states and the organisation to rededicate themselves to the original principles of the organisation.

Economic diversification and good governance must go hand in hand with sustained, inclusive development policies and programmes aimed at redistributing 
wealth and income, in favour of disadvantaged groups that constitute the majority, to give every citizen a voice in decision-making processes that affect their lives. At the institutional level, ECOWAS should encourage members to put in place transparent and effective strategies beyond their formal Youth Policy Documents. It should nudge members to undertake the following measures, among many others: first, they should revamp outmoded curricula in all sectors of their educational systems, so that young school leavers and graduates will possess the requisite skills and be employable, and expose them to vocational life skills training for self-employment. Sadly, while the ICT revolution has catapulted states in the global North into the fourth industrial revolution, West Africa and sub-Saharan Africa are yet to embrace the first one successfully. ${ }^{17}$

Second, ECOWAS should rededicate itself to the pursuit of a two-track approach to regional integration, promoting economic development and wealth, and consolidating the creation of a security community to attract desperately needed foreign investment into the region. Third, ECOWAS should encourage member states to implement "tax incentive measures and programmes for the employability of young graduates by companies and the acquisition of first work experience" (UNECA, 2015, xiv). ECOWAS should set an example in spearheading genuine reform of agriculture by increasing investment in this vital sector, providing transport infrastructure that will open up remote rural areas, to choke off the urban-rural drift of young and largely illiterate youth. Effective investment in the agricultural sector could lead to genuine income redistribution through enhanced earnings for farmers, in a way that would checkmate the vicious cycle of what sociologists call "transmission of poverty" from one generation to another. It is remarkable in this regard that the Southeast Asian "economic miracle" was driven by substantial investment in the agricultural sector, which in some instances was as high as 25 percent of national budgets, among other pro-people measures and policies (Eyinla, 2012, 1).

Fourth, ECOWAS must establish a department at its headquarters in Abuja that is exclusively responsible for coordinating regional integration issues. It should encourage effective mechanisms at the national level to coordinate regional programmes and policies. There is real need for the re-establishment of vital links between member states and citizens to deepen economic integration in the region. ECOWAS should also encourage members to adhere to the protocol on terrorism as well as the 2006 ECOWAS Convention on Small Arms and Light Weapons, their Ammunition, and other Related Matters, especially after the collapse of the regime of Muammar Gaddafi in Libya in 2011, and its ramifications for peace and security in West Africa. ECOWAS must, therefore, work closely with other stakeholders to fully operationalise the "Sahel Strategy and strengthen crisis management mechanisms to contain the security and terrorism risks" (UNECA, 2015, xiv). ECOWAS needs to be actively involved in coordinating the actions and responses of critical non-member countries such as Algeria, Chad, Libya, Mauritania, and Morocco and important development partners, including the AU, the US, and the EU, to fast-track the operationalisation of the Sahel Strategy. 
Fifth, ECOWAS should work towards the full establishment and operationalisation of a logistics depot to enhance its response capacity and facilitate the standardisation of equipment for enhanced local ownership. Closely related is the need for financial self-sufficiency, which is critical to sustainability and local ownership of peace support operations. The Mali After-Action Review rightly noted: "to ensure its rapidity and flexibility, safeguard secrecy and confidentiality to achieve successful outcomes, a PSO [peace support operation] must be endowed with an autonomous, consolidated and dedicated fund." ECOWAS should seriously consider holding annual fundraising activities within and outside the region every year to celebrate "ECOWAS Day." "ECOWAS Day" should be used to raise money for the ECOWAS Peace Fund. ECOWAS should encourage successful local and foreign corporate entities such as banks and oil companies, which are among the major beneficiaries of peace and stability in the region, to donate to the Fund. The West African Diaspora and friends of ECOWAS should be encouraged to donate generously. A Board of Trustees comprising notable individuals in and outside of the region should manage ECOWAS Day donations (ECOWAS, 2014, 31).

The need for effective communication during peace support operations cannot be overstated. Poor or even lack of efficient communication channels has been the bane of ECOWAS military missions dating back to Liberia in 1990. It was also a major challenge in the Mali mission. There is urgent need to put in place a "dedicated and secure communications, and simple administrative and procurement procedures (for such purpose) outside the normal (ECOWAS) bureaucracy" (ECOWAS, 2014, 31). A good starting point is to sufficiently fund the Communications Directorate at the headquarters in Abuja, to build its capacity to drive the new orientation. Finally, ECOWAS must work towards the realisation of Vision 2020 in line with its determination to transform "an ECOWAS of States into an ECOWAS of People Democratic and Prosperous" (ECOWAS, 2011). The organisation should, therefore, continue to engage closely and continuously with civil society forces and organisations in the region to benefit from their invaluable support in marketing its programmes and policies. ${ }^{18}$

\section{Notes}

1 President Ahmed Sékou Touré of Guinea was noted for having very frosty relations with some of his Francophone and Anglophone neighbours

2 The last border skirmish between ECOWAS members occurred in 1984 between Mali and Burkina Faso but was quickly brought under control through the timely intervention of Nigeria's former foreign minister Bolaji Akinyemi.

3 In the 2015 revised 1999 Mechanism.

4 Hundreds of civilians, including ECOWAS nationals who took refuge in holy places and in diplomatic missions, were being massacred indiscriminately by all sides in the uncivil war. Most of the more comprehensive literature on the intervention in Liberia discussed this aspect.

5 The UN took over the Mali Mission from the AU and ECOWAS less than two years into the operation due to funding and logistical challenges.

6 Interview with Mr Osei, former director, economic planning and research department, ECOWAS Commission, Abuja, June 2007. 
7 Adekeye Adebajo has made this point forcefully, directly, and indirectly, in some of his works. See, for instance, Adebajo (2002, 2004a, 2004b).

8 See, for example, Sesay and Akinrinade (1996) and Shuaibu (2015).

9 Sabotage of oil production facilities so disruptive that the Nigerian government is alleged to have reached an agreement with them, which at one point involved the release of the Okah brothers, who were sentenced in connection with bombings in Abuja in October 2010. In April 2020 crude oil price was $\$ 16.46$ less than the production cost of $\$ 30$.

10 Various national newspapers ran stories on the recession; for example The Nation (2016) and Vanguard (2016).

11 For instance, the price of crude oil, the country's major foreign exchange earner, was only USD \$27 a barrel in January 2016, while the budget was pegged at USD \$38, with a daily production rate of 2.2 million barrels. Production dropped steeply to 1.2 million in July 2016 due to the activities of the Niger Delta Avengers.

12 See Vanguard, 20 July 2016.

13 For more on this argument see, Sesay (2016).

14 Nigeria pulled out of the Mali Mission unexpectedly blaming it on the need to concentrate on the war against Boko Haram in its northeast.

15 The visit led to the release of Nigeria's contributions to the ECOWAS budget for 2015 and 2016, totaling USD $\$ 694,000$. The minister also promised to provide the ECOWAS president with accommodation to save costs. It has been alleged that the money was deliberately withheld in protest at the Commission's profligacy, especially during his predecessor's tenure, which left it virtually bankrupt.

16 The most notorious examples are perhaps Liberia and Sierra Leone, which imploded in the early 1990s.

17 This is why African states and citizens are referred to as "ICT migrants" as opposed to "ICT citizens" as is the case in technologically developed countries.

18 I am not sure of the percentage of ECOWAS citizens that presently know of its existence, even after four decades of its existence, having been founded in July 1975.

\section{References}

Aboagye, F. (1999). ECOMOG: A sub-regional experience in conflict resolution, management, and peacekeeping in Liberia. Accra: SEDCO.

Adebajo, A. (2002). Building peace in West Africa. Liberia, Sierra Leone, and Guinea Bissau. Boulder, CO: Lynne Rienner.

Adebajo, A. (2004). Pax West Africana? Regional security mechanisms. In A. Adebajo and I.O.D. Rachid (Eds.), West Africa's security challenges: Building peace in a troubled region. Boulder, CO: Lynne Rienner Publishers.

Adebajo, A. (2004a). Introduction. In A. Adebajo and I.O.D. Rachid (Eds.), West Africa's security challenges: Building peace in a troubled region. Boulder, CO: Lynne Rienner.

Adebajo, A. (2004b). Pax West Africana? Regional security mechanisms. In A. Adebajo and I.O.D. Rachid (Eds.), West Africa's security challenges: Building peace in a troubled region. Boulder, CO: Lynne Rienner.

Adedeji, A. (2004). ECOWAS: A retrospective journey. In A. Adebajo and I. O. D. Rachid (Eds.), West Africa's security challenges: Building peace in a troubled region. Boulder, CO: Lynne Rienner.

Adeshina, R.A. (2002). The reversed victory: The story of Nigerian military intervention in Sierra Leone. Ibadan: Heinemann Educational Books.

Adisa, J. (1993). Nigeria in ECOMOG: The burden of community spirit. In J. Owoeye, (Ed.), Nigeria in international institutions. Ibadan: College Press. 
Aning, E.K. (1994). Africa's security problematic in the Post-Cold War era (CDR Working Paper 94.11). Denmark: Centre for Development Research.

Aning, E.K. (1999). Peacekeeping under ECOMOG: A sub-regional approach. In J. Cilliers and G. Mills (Eds.), From peacekeeping to complex emergencies. Johannesburg: SAIIA \& IISS.

Asante, S.K.B. (2004). The travails of integration. In A. Adebajo and I.O.D. Rachid (Eds.), West Africa's security challenges: Building peace in a troubled region. Boulder, CO: Lynne Rienner.

Bach, D. (1993). The politics of West African economic co-operation: CEAO and ECOWAS. Journal of Modern African Studies, 21(4), 605-62.

Bach, D. (2004). The dilemmas of regionalization. In A. Adebajo and I.O.D. Rachid (Eds.), West Africa's security challenges: Building peace in a troubled region. Boulder, CO: Lynne Rienner.

Blank News Online. (n.d.). Retrieved on May 30, 2016, from www.blanknewsonline .wordpress.com.

Cheru, F., and Obi, C. (Eds.). (2010). The rise of China and India in Africa. London: Zed Books.

Daily Vanguard (2016a, July 20). It's official: Economy in recession.

Daily Vanguard (2016b, July 20). Nigeria's economy in bad shape.

ECOWAS. (2000). Interim report by the executive secretary (ECW/CMVLVV1/2).

ECOWAS. (2011). ECOWAS vision, 2020. Abuja.

ECOWAS. (2014). Maliafter-action review of ECOWAS initiatives and responses to the multidimensional crises in Mali, November 2013 to February 2014.

ECOWAS Mediation Facilitation Division. (n.d.). ECOWAS mediation (p. 7). Abuja: ECOWAS Commission.

Eyinla, B. (2012). Comparative development trajectories: Sub-Sahara Africa and Southeast Asia (Unpublished monograph, p. 1). Johannesburg: Mandela Institute of Development Studies (MINDS).

Financial Watch. (n.d.). Retrieved on May 30, 2016, from http://www.financialwatchngr .com.

Runsewe, O. (2016, January 18). What a Mali-Burkina Faso anti-terrorism coalition will mean for West Africa. Ventures Africa. Retrieved July 28, 2016, from http://ventures africa.com/what-a-mali-burkina-faso-anti-terrorism-coalition-means-for-west-africa/.

Sesay, A. (2008a). The African union, problems and prospects (Lecture delivered to Course 14). Abuja: National War College.

Sesay, A. (2008b). Where are the leaders of the regional grouping? The AU, Regional Economic Communities, RECs, and the maintenance of regional security. Paper presented at a two-day workshop on Nigeria's Security Interest in Africa, NIIA/ Ministry of Foreign Affairs, Abuja, May 1-3.

Sesay, A. (2016). Foreign policy as an instrument of development. University of Ilorin, Department of Political Science.

Sesay, A., and Akinrinade, S. (1996). The impact of the structural adjustment program on the structure of Nigeria's international economic relations (Working Paper No. 13). Ibadan: NISER/IDRC.

Sesay, A., and Omotosho, M. (2011). ECOWAS and the politics of integration in West Africa. WACSERIES 2(2). Accra, Ghana: West Africa Civil Society Initiative.

Shuaibu, M. (2015). Trade liberalization and intra-regional trade: A case of selected ECOWAS countries. African Development Review, 27(1), 27-40. 
Southall, R., and Melber, H. (Eds.). (2009). A new scramble for Africa? KwaZulu-Natal: University of KwaZulu-Natal.

The Nation. (2016, July 20). Govt: Economy in recession.

UNECA. (2015). Socio-economic profile of West Africa in 2014 and prospects for 2015. Addis Ababa.

Vines, A., Wong, L., Weimer, M., and Campos, I. (2009). Thirst for African oil: Asian national oil companies in Nigeria and Angola. London: Royal Institute of International Affairs. 